\title{
PELATIHAN DETEKSI DINI TUMBUH KEMBANG DAN PIJAT BAYI BAGI KADER POSYANDU BANJAR MUNGENGAN, CATUR, KINTAMANI
}

\author{
Indah Pramita ${ }^{1}$, Ni Made Diaris ${ }^{2}$, Resti Kusumarini Samben ${ }^{3}$ \\ ${ }^{1}$ Program Studi Fisioterapi, Universitas Dhyana Pura \\ ${ }^{2}$ Program Studi Perekam Informasi Kesehatan, Universitas Dhyana Pura \\ ${ }^{3}$ Program Studi IImu Gizi, Universitas Dhyana Pura \\ e-mail: indahpramita@undhirabali.ac.id,madediaris@undhirabali.ac.id, \\ restisamben@undhirabali.ac.id
}

\begin{abstract}
Abstrak
Posyandu (Pos Pelayanan Terpadu) merupakan salah satu bentuk upaya kesehatan yang bersumberdaya dari masyarakat. Posyandu Banjar Mungsengan Desa Catur Kecamatan Kintamani termasuk dalam tingkat madya yang memiliki 6 kader dengan tingkat pendidikan yang masih rendah, yaitu SMP dan SMA. Berdasarkan wawancara dengan Ketua Posyandu, diketahui pernah terdapat kasus balita yang mengalami keterlambatan bicara. Namun, kader belum mampu melakukan deteksi dini tumbuh kembang dan belum mampu melakukan stimulasi tumbuh kembang guna untuk membantu mengatasi masalah tersebut. Berdasarkan wawancara dan observasi didapatkan 2 aspek permasalahan yaitu: kurangnya keterampilan kader tentang deteksi dini tumbuh kembang dan ketidak mampuan memberikan stimulasi tumbuh kembang. Adapun solusi untuk permasalahan aspek SDM kader yaitu 1) Pelatihan deteksi dini tumbuh kembang dengan menggunakan Kuisioner Pra Screning Perkembangan; 2) Pelatihan pijat bayi bagi kader. Dalam kegitan ini juga diberikan panduan berupa modul dan video pijat bayi untuk membantu kader memahami serta mengaplikasikan pijat bayi. Hasil dari program kemitraan masyarakat ini adalah terjadi peningkatan keterampilan kader dalam melakukan deteksi dini tumbuh kembang sebesar $80 \%$, dan peningkatan keterampilan kader dalam mengaplikasikan pijat bayi rata-rata sebesar $75 \%$.
\end{abstract}

Kata Kunci : deteksi dini, tumbuh kembang, pijat bayi, kader, posyandu

\begin{abstract}
Integrated Service Post is a form of health effort that comes from the community. Integrated Service Post Banjar Mungsengan, Catur Village, Kintamani Subdistrict, is included in the middle level which has 6 cadres with low levels of education, namely SMP and SMA. Based on the interview with the chairman, it is known that there have been cases of toddlers who experience speech delays. However, cadres have not been able to do early detection of growth and development and have not been able to stimulate growth and development in order to help overcome the problem. Based on interviews and observations, 2 aspects of the problem were found, namely: the lack of skills of cadres about early detection of growth and development and the inability to stimulate growth and development. The solutions to the problems of the cadres' HR aspects are 1) Training on early detection of growth and development using the Pre Development Screning Questionnaire; 2) Infant massage training for cadres. In this activity, guidance is also given in the form of infant massage modules and videos to help cadres understand and apply baby massage. The result of this community partnership program was an increase in the skills of cadres in early detection of growth and development by $80 \%$, and an increase in cadres' skills in applying infant massage by an average of $75 \%$.
\end{abstract}

Keywords: early detection, growth and development, baby massage, cadre 


\section{PENDAHULUAN}

Posyandu (Pos Pelayanan Terpadu) merupakan salah satu bentuk upaya kesehatan yang bersumberdaya dari masyarakat. Posyandu memberikan kemudahan kepada masyarakat dalam memperoleh informasi dan pelayanan kesehatan bagi ibu hamil, bayi dan balita. Dalam kegiatan posyandu akan ada peran kader yang membantu berlangsungnya proses pelayanan kesehatan. Kader tidak hanya bertugas mencatat data, namun juga bertugas memberikan penyuluhan, memberikan makanan tambahan, berkoordinasi dengan orang tua tentang tumbuh kembang anak dan berkoordinasi dengan tenaga kesehatan.

Posyandu Banjar Mungsengan terletak di Desa Catur Kecamatan Kintamani Kabupaten Bangli. Posyandu ini temasuk posyandu tingkat madya yang memiliki 6 kader dalam kepengurusannya. Keenam kader yang ada di posyandu tersebut memiliki tingkat pendidikan yang masih tergolong rendah, yaitu SMP dan paling tinggi SMA. Selama menjadi kader mereka pernah mengikuti pelatihan pengisian kartu menuju sehat yang diadakan oleh puskesmas setempat. Posyandu ini melaksanakan kegiatannya 1 kali dalam sebulan yaitu pada tanggal 23 . Kegiatan yang dilakukan setiap bulan adalah melakukan pemeriksaan Tinggi badan, Berat badan, Lingkar kepala, status gizi bagi bayi dan balita serta pemberian vitamin, imunisasi dan makanan tambahan. Kegiatan dilakukan di Bale Banjar Mungsengan Desa Catur dibantu oleh seorang tenaga kesehatan dari puskesmas setempat. Kegiatan posyandu diikuti oleh 34 balita dan 6 bayi. Selama kegiatan balita langsung menuju meja pemeriksaan untuk melakukan pengukuran tinggi badan, berat badan serta pemberian vitamin.

Berdasarkan wawancara dengan Ketua Posyandu yaitu Ibu Ni Wayan Restiti, diketahui bahwa pernah terdapat balita yang mengalami keterlambatan bicara. Hal ini dikarenakan tingkat pendidikan kader yang rendah serta kurangnya pemahaman kader tentang deteksi dini dan stimulasi tumbuh kembang. Mereka hanya mengetahui tumbuh kembang anak secara garis besar atau yang tertera dalam Kartu Menuju Sehat (KMS), dan belum mampu menyampaikan informasi kepada orang tua. Diharapkan dengan adanya pelatihan deteksi dini tumbuh kembang, kader mampu melakukan deteksi dini pertumbuhan dan perkembangan anak sesuai dengan usianya. Sehingga masalah keterlambatan tumbuh kembang dapat dimanagement dengan baik.

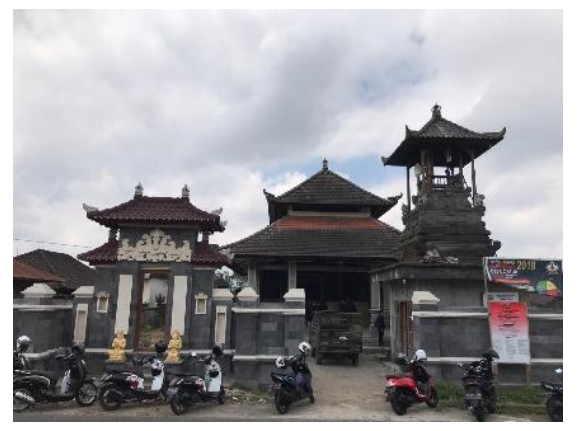

Gambar 1. Banjar Mungsengan tempat pelaksanaan kegiatan

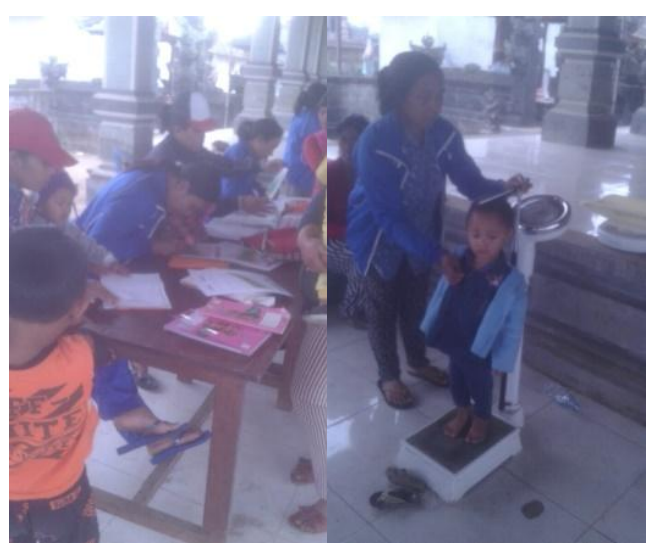

Gambar 2. Pelaksanaan kegiatan posyandu

\section{METODE}

Kegiatan dilaksanakan di Bale Banjar Mungsengan Desa Catur Kecamatan Kintamani Kabupaten Bangli. Adapun langkah-langkah kegiatan yaitu:

(1) Sosialisasi kegiatan dengan menghadirkan mitra dalam sebuah rapat.

Kegiatan ini dilaksanakan di Balai Banajr Mungsengan dan dihadiri oleh Semua kader posyandu Banjar 
Mungsengan. Dalam kegiatan ini dijelaskan tentang kegiatan yang akan dilaksanakan yaitu adanya pelatihan deteksi dini tunbuh kembang dan juga pelatihan pijat bayi. Diharapkan dengan adanya oelatihan ini nanti kader posyandu mampu melakukan deteksi dini tumbuh kembang sesuai usia anak dan juga mampu melakukan pijat bayi.

(2) Pelatihan deteksi dini tumbuh kembang bagi kader

Pelatihan deteksi dini tumbuh kembang diberikan kepada 6 kader posyandu banjar mungsengan. Kegiatan dilaksanakan tanggal 21 Juni 2020 di Balai Banjar Mungsengan. Pelatihan deteksi dini diberikan dengan memberikan pemahaman tentang Kuisioner Pra Screaning Perkembangan pada anak umur 3 bulan sampai dengan 72 bulan. Disini diharapkan kader posyandu mampu melakukan screening perkembangan anak sesuai dengan usianya.

(3) Pembuatan modul pijat bayi

Dalam kegiatan ini juga akan diberikan panduan berupa modul pijat bayi. Pengabdi menyusun modul pijat bayi berdasarkan beberapa sumber jurnal dan juga buku pijat bayi. Dalam modul ini juga dilengkapi dengan gambar untuk memudahkan dalam mengaplikasikan pijat bayi

(4) Pembuatan video pijat bayi

(5) Pelatihan pijat bayi bagi kader dan orang tua

Pelatihan Pijat bayi diberikan untuk meningkatkan ketrampilan kader dalam melakukan stimulasi tumbuh kembang. Pelatihan Pijat Bayi kepada kader diberikan kepada 6 kader posyandu pada tanggal 28 Juni 2020. Dalam kegiatan ini pengabdi memberikan pelatihan secara langsung kepada akder, dimana terlebih dahulu pengabdi mencontohkan cara melakukan pijat bayi secara keseluruhan. Kemudian selanjutnya meminta kader mengaplikasikan pijat bayi secara kangsung dengan menggunakan boneka bayi. Evaluasi dilakukan saat kader mengaplikasikan pijat bayi.

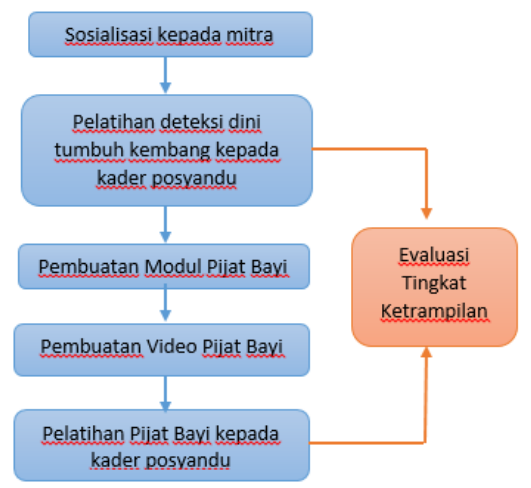

Gambar 3. Diagram alur pelaksanaan

\section{HASIL DAN PEMBAHASAN}

Kegiatan pengabdian masyarakat diawali dengan melakukan sosialisasi kegiatan bersama dengan mitra. Ketua Desa lbu Ana Setyowati dan juga ketua Posyandu Banjar Mungsengan lbu $\mathrm{Ni}$ Wayan restiti sangat mendukung kegiatan ini. Mereka sangat antusias supaya kegiatan pengabdian ini segera dilaksanakan sehingga perkembangan bayi dan balita di Bajjar Mungsengan bisa optimal. Setelah melakukan sosialisasi kegiatan selanjutnya adalah melaksanakan pelatihan deteksi dini tumbuh kembang kepada kader, kemudian tim pengabdi membuat modul dan juga video pijat bayi. Selanjutnya dilaksanakan pelatihan pijat bayi kepada kader posyandu. Dalam kegiatan ini tingkat keberhasilan akan dinilai berdasarkan keterampilan kader dalam melakukan deteksi dini tumbuh kembang dan juga pijat bayi.

(1) Pelatihan deteksi dini tumbuh kembang bagi kader posyandu

Pelatihan deteksi dini tumbuh kembang diberikan kepada 6 kader Posyandu di Banjar Mungsengan. Kegiatan dilaksanakan pada tanggal 21 Juni 2020 di Balai Banjar Mungsengan Desa Catur. Kegiatan dilaksanakan dengan mengikuti protokol kesehatan covid 19 yang dikeluarkan oleh Universitas Dhyana Pura. 


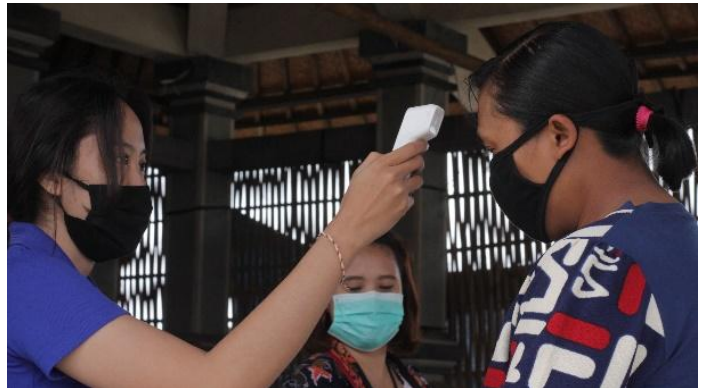

Gambar 4. Pemeriksaan Suhu tubuh peserta pelatihan

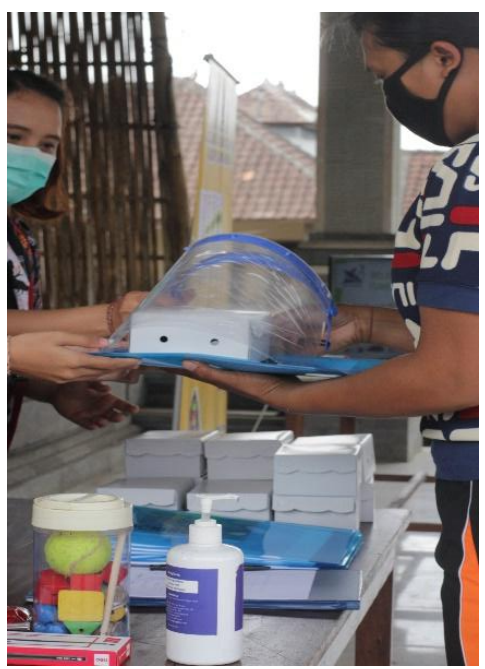

Gambar 5. Pembagian Face Shield Kepada Peserta Pelatihan

Kader posyandu Mungsengan sangat antusias dalam mengikuti kegiatan deteksi dini tumbuh kembang. Sebelum kegiatan dimulai dilakukan penilaian tentang ketrampilan melakukan deteksi dini dengan menggunakan Kuisioner Pra Screaning Perkembangan (KPSP). Kader posyandu mungsengan belum mengetahui apa itu Form KPSP dan tidak tau bagaimana cara mengaplikasikannya. Selanjutnya tim pengabdi memberikan pelatihan deteksi dini tumbuh yang diisi oleh lbu Indah Pramita, SST.FT, M.Fis. Pelatihan dengan form KPSP diberikan mulai bayi umur 3 bulan sampai dengan 72 bulan. Pelatihan berlangsung selama 4 jam, Narasumber menjelaskan dengan detail dan memperagakan bagaimana cara melakukan deteksi dini tumbuh kembang dengan menggunakan form KPSP, selanjutnya diakhir kegiatan dilakukan evaluasi untuk menilai tingkat ketrampilan kader dalam melakukan deteksi dini dengan menggunakan form KPSP. Dalam evaluasi kader diminta melakukan deteksi dini sesuai dengan form KPSP, disini dilihat keterampilan kader dalam melakukan deteksi dini.

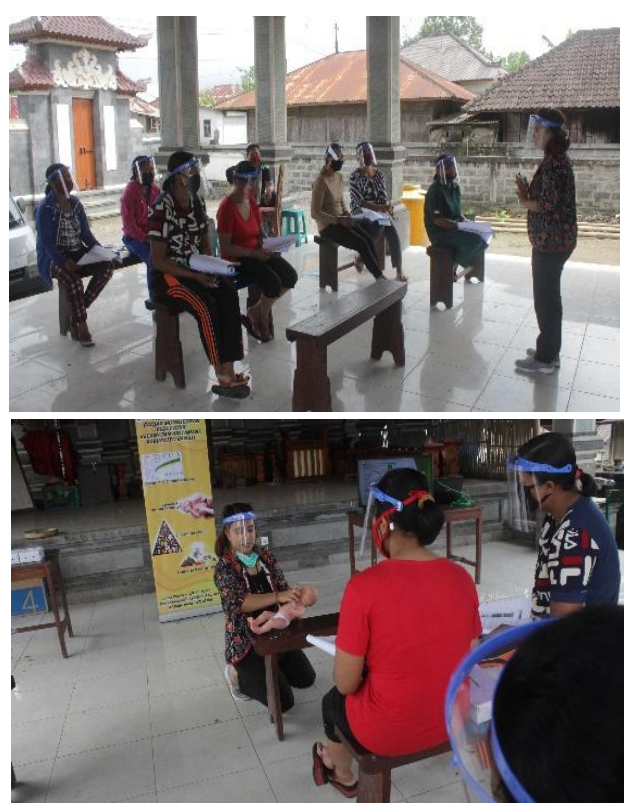

Gambar 6. Kader posyandu mengikuti pelatihan deteksi dini tumbuh kembang

Setelah mengikuti pelatihan deteksi dini, terlihat ketrampilan kader meningkat. Dimana awalnya semua kader tidak mampu melakukan deteksi dini dengan form KPSP sekarang sudah mampu dan memiliki tingkat ketrampilan sebesar $80 \%$. Berikut hasil penilaian tingkat ketrampilan kader dalam melakukan deteksi dini tumbuh kembang dengan menggunakan form KPSP.

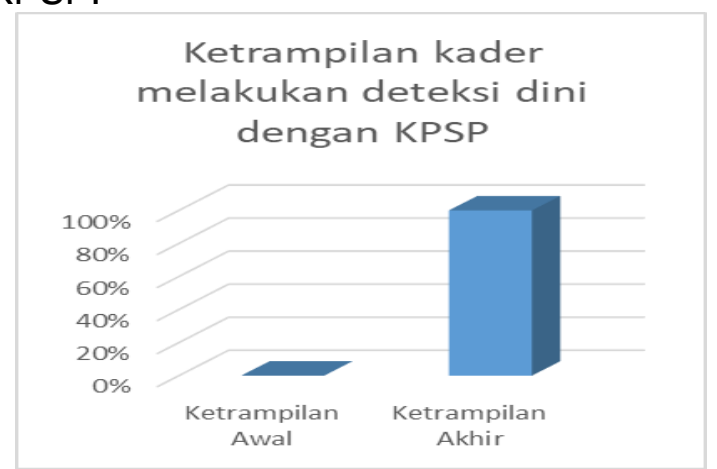

Gambar 7. Tingkat keterampilan kader melakukan deteksi dini tumbuh kembang 
(2) Pelatihan Pijat bayi kepada kader

Pelatihan pijat bayi diberikan kepada

6 kader posyandu mungsengan. Kegiatan dilaksanakan pada tanggal 28 Juni 2020 di Balai Banjar Mungsengan. Sebelum memulai kegiatan, selalu dilakukan protocol kesehatan terlebih dahulu dengan mengecek suhu setiap peserta kegiatan, mencuci tangan dengan sabun/ menggunakan hand sanitaiser dan tak lupa menggunakan masker/face shield selama kegiatan berlangsung. Pelatihan pijat bayi diberikan oleh ketua pengabdi, Indah Pramita, SST.Ft., M.Fis.

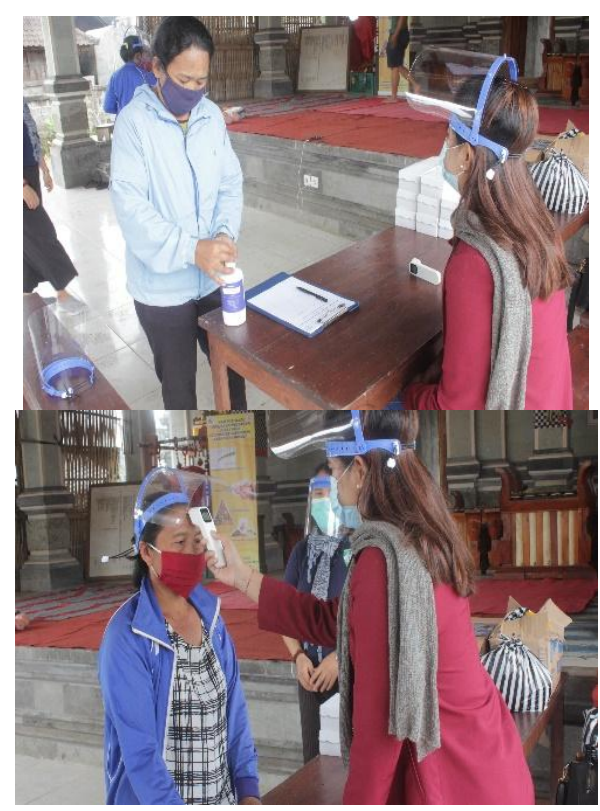

Gambar 8. Penerapan protokol kesehatan Covid- 19 sebelum pelatihan

Pengabdi memberikan contoh terlebih dahulu bagaimana melakukan pijat bayi kepada balita, sembari memberikan contoh tak lupa diberikan juga penjelasan tentang manfaat serta aturan selama melakukan pemijatan kepada balita. Tahap selanjutnya masing-masing kader diberi kesempatan untuk mengaplikasikan pemijatan langsung dengan menggunakan model (phantom bayi). Kesempatan diberikan sebanyak 2 kali pengulangan.
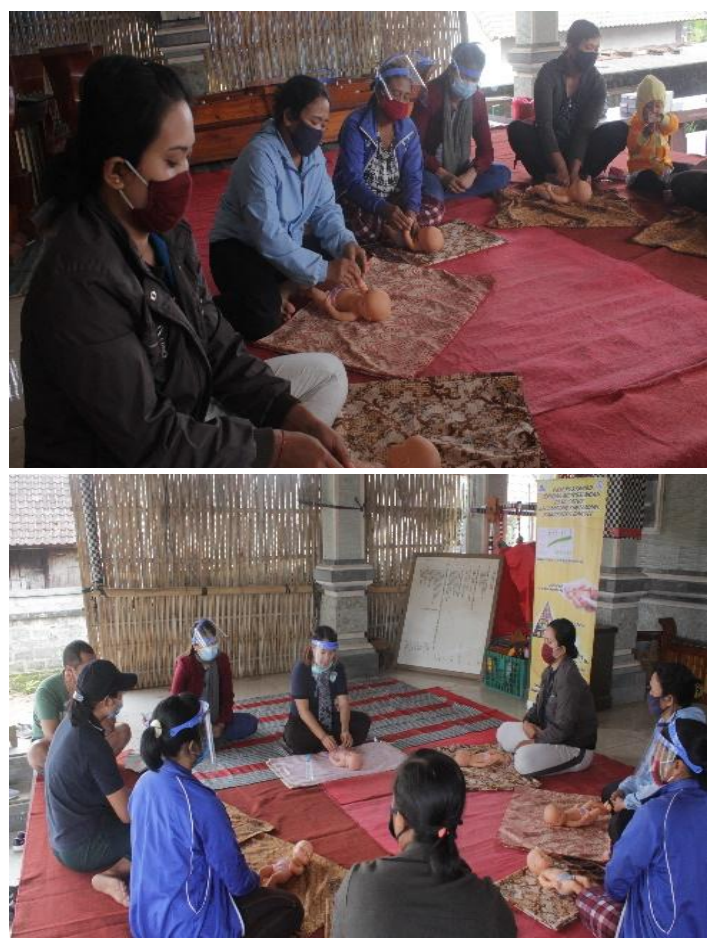

Gambar 9. Kader posyandu mengikuti pelatihan pijat bayi

Pada tahap akhir dilakukan penilaian keterampilan kader dalam mengaplikasikan pijat bayi dengan menggunkan form cheklish tiap bagian tubuh balita, berikut hasilnya :

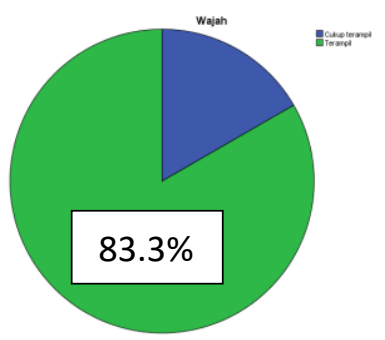

a.Wajah

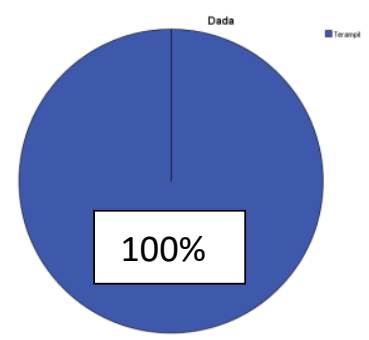

b.Dada
Gambar 10. Keterampilan pijat area wajah dan dada

Pada gambar terlihat bahwa 83,3\% kader posyandu mampu mengaplikasikan pijat bayi pada area wajah dengan terampil, dan $100 \%$ kader mampu mengaplikasikan pijat pada area dada dengan terampil 


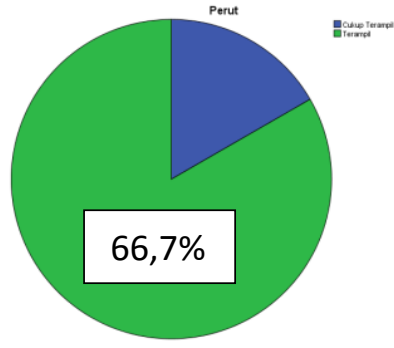

a.Perut

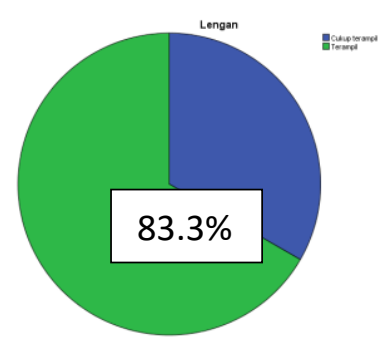

b.Lengan
Gambar 11. Keterampilan pijat area perut dan lengan

Pada gambar terlihat bahwa 83,3\% kader posyandu mampu mengaplikasikan pijat bayi pada area perut dengan terampil, dan $66,7 \%$ kader mampu mengaplikasikan pijat pada area dada dengan terampil.

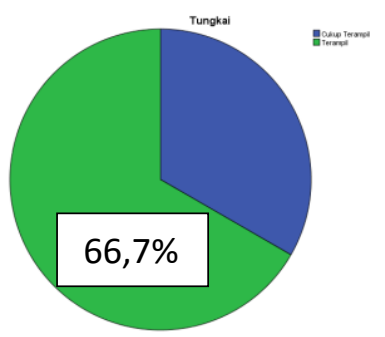

a.Tungkai

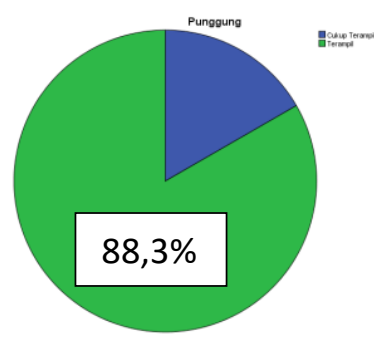

b.Punggung
Gambar 12. Keterampilan pijat area tungkai dan pungung

Pada gambar terlihat bahwa $66,7 \%$ kader posyandu mampu mengaplikasikan pijat bayi pada area tungkai dengan terampil, dan 83,3\% kader mampu mengaplikasikan pijat pada area punggung dengan terampil.

\section{KESIMPULAN}

Kesimpulan yang didapat dalam program kemitraan masyarakat posyandu banjar mungsengan desa catur kecamatan kintamani kabupaten bangli sebagai berikut:

(1) Keterampilan kader posyandu dalam melakukan deteksi dini tumbuh kembang mengalami peningkatan menjadi $80 \%$
(2) Keterampilan kader dalam memakukan pijat bayi meningkat, $83.3 \%$ kader mampu melakukan pijat bayi dengan terampil di area wajah, $100 \%$ kader melakukan pijat bayi dengan terampil di area dada, $83.3 \%$ kader mampu melakukan pijat bayi dengan terampil di area perut, 66,7\% kader mampu melakukan pijat bayi dengan terampil di area lengan, 66,7\% kader mampu melakukan pijat bayi dengan terampil di area tungkai, 83.3\% kader mampu melakukan pijat bayi dengan terampil di area punggung.

\section{UCAPAN TERIMAKASIH}

Penulis mengucapkan terimakasih kepada :

(1) Direktorat Riset dan Pengabdian Masyarakat Direktorat Jenderal Penguatan Riset dan Pengembangan Kementerian Riset dan Teknologi/Badan Riset dan Inovasi Nasional atas dana hibah PKM yang telah diberikan sehingga kegiatan ini bisa berjalan dengan lancar dan sukses.

(2) Lembaga Penelitian dan Pengabdian Masyarakat Universitas Dhyana Pura, atas bantuan dan arahan sehingga kegiatan PKM ini dapat terlaksana.

(3) Kepala Desa Catur, Kintamani yang memberikan dukungan sehingga kegiatan PKM dapat terselenggara dengan baik.

(4) Kepala dusun dan Ketua Posyandu Banjar Mungsengan ang merupakan mitra kegiatan, yang membantu terlaksananya kegiatan PKM ini.

\section{DAFTAR PUSTAKA}

Sawitry, S., Kuntjoro, T., \& Ariyanti, I. (2019). Pengaruh Pijat Bayi Terhadap Berat Badan Dan Lama Tidur BAYI. MMJ (Mahakam Midwifery Journal), 2(5), 330-336.

Suharto, S., \& Suriani, S. (2018). Pengaruh Pijat Bayi terhadap Peningkatan Motorik Kasar dan Motorik Halus Bayi Usia 3-24 Bulan di Klinik Fisioterapi Sudiang Makassar. Media Kesehatan Politeknik Kesehatan 
Simanjuntak, C. A., Fitri, A. D., \& Puspasari, A. (2017). Deteksi Dini Dan Edukasi Orang Tua Tentang Gangguan Tumbuh Kembang Balita. Jurnal Karya Abdi Masyarakat, 1(1), 14-17

Poernomo, D. I. S. H., \& Anggraeni, S. (2012). Pengaruh Pemberian Makanan Tambahan Pemulihan (PMT-P) Terhadap Pertumbuhan Balita Bawah Garis Merah (BGM) Di Puskesmas Kota Wilayah Selatan Kediri. Jurnal Penelitian STIKES Kediri, 4(1), 1-7
Ni'mah, K., \& Nadhiroh, S. R. (2016). Faktor yang berhubungan dengan kejadian stunting pada balita. Media Gizi Indonesia, 10(1), 13-19

Septiana, R., Djannah, S. N., \& Djamil, M. D. (2010). Hubungan Antara Pola Pemberian Makanan Pendamping ASI (MP-ASI) dan Status Gizi Balita Usia 6-24 Bulan di Wilayah Kerja Puskesmas Gedongtengen Yogyakarta. Kes Mas: Jurnal Fakultas Kesehatan Masyarakat Universitas Ahmad Daulan, 4(2). 